\title{
Notices
}

Avis

\section{EXTRACT FROM THE CONSTITUTION OF THE CANADIAN POLITICAL SCIENCE ASSOCIATION}

\section{ARTICLE VI: ELECTIONS}

1 The nominating committee ... shall prepare a selection of names for all offices which are to be filled by election, at the next annual meeting of the Association, including elective members to the nominating committee. It shall ensure the inclusion of at least one name from each of: the Atlantic provinces, Quebec, Ontario, the Prairie provinces, and British Columbia.

2 The Secretary-Treasurer shall send the nominating committee's selections to all members of the Association at the same time that the notice of the annual meeting is circulated.

3 Nominations of other candidates may be made by any two members, submitting a nomination paper signed by themselves and the nominee, to the Secretary-Treasurer at or before the annual meeting.

6 Only members of the Association are eligible to hold office and to vote.

\section{EXTRAIT DES STATUTS DE L'ASSOCIATION CANADIENNE DE SCIENCE POLITIQUE}

\section{ARTICLE VI: ELECTION DU BUREAU DE DIRECTION}

1 Le comité des candidatures ... préparera une liste de candidats pour tous les postes à pourvoir (y compris les membres électifs du comité des candidatures) lors de la prochaine assemblée annuelle de l'Association. A cet égard, le comité devra porter sur cette liste au moins un représentant de chacune des régions suivantes : Terre-Neuve et les provinces maritimes, Québec, Ontario, les provinces de l'Ouest et la Colombie Britannique.

2 Le secrétaire-trésorier fera parvenir à tous les membres de l'Association la liste préparée par la comité des nominations en adressant le programme de la conférence annuelle.

3 Deux membres pourront proposer tout autre candidature; a cet effet, ils devront remettre au secrétaire-trésorier, avant ou pendant l'assemblée annuelle.

6 Seuls les membres de l'Association sont éligibles aux différents postes et ont le droit de vote. 